\title{
PERUBAHAN KANDUNGAN NITROGEN, PHOSPAT DAN KALIUM PADA PENYIMPANAN PUPUK NPK
}

\author{
Oleh : \\ Yuni Adiningsih *)
}

\begin{abstract}
ABSTRAK
NPK fertilizer is fertilizer containing Nitrogen, Phosphate and Potassium elemen. There elements have easyly soluble in water ions and do not resist to the sun rays (heat) easyly volatility. Due to the treatment of indoor and outdoor storing, all of Nitrogen. Phosphate and Potassium elements decrease in concentration and the most significant effect of storing is the indoor storing.

In the treatment of storing duration, the results of 2 weeks duration is different with 4 weeks duration both for indoor and outdoor storing. A long time storing decrease the concentration of Nitrogen, Phosphate and Potassium in fertilizer. The result of moisture content testing of fertilizer treated with heat and rain are higher than the fertilizer stored indoor treatment.
\end{abstract}

Keywords: Fertilizer, storing, concentration decreasing

\section{PENDAHULUAN}

K

eberhasilan produksi pertanian melalui kegiatan intensifikasi tidak terlepas dari kontribusi dan peranan sarana produksi, antara lain pupuk. Untuk menjaga konsistensi mutu produk dari produsen sampai ke konsumen serta untuk menjaga agar kandungan yang tertera di label sama dengan produknya, di mana ada kecenderungan unsur-unsur dari pupuk NPK dapat bereaksi dengan air atau udara sekitar maka perlu dilakukan suatu penelitian untuk melihat pengaruh penyimpanan pupuk NPK padat terhadap mutu produk asalnya.

Di samping itu pemakaian pupuk dengan mutu ( kandungan hara) yang tidak sama dengan label akan merugikan petani karena untuk memberikan pupuk pada tanaman perlu perhitungan yang cermat. Apabila tanaman kelebihan/kekurangan salah satu unsur hara yang terdapat dalam pupuk, maka akan mempunyai dampak pada tanah maupun pada kehidupan tanaman itu sendiri.

Unsur Nitrogen pada pupuk NPK merupakan salah satu satu unsur hara esensial bagi tanaman. Nitrogen diambil oleh tanaman dalam bentuk ion Amonium $\left(\mathrm{NH}_{4}{ }^{+}\right)$dan ion Nitrat $\left(\mathrm{NO}_{3}{ }^{-}\right)$. Unsur ini bersifat labil, mudah tercuci dan menguap (http://www.warungpupuk.com). Dibanding unsur lainnya yaitu Phospat dan Kalium, Nitrogen lebih banyak mendapat perhatian karena sifat dari unsur tersebut yang labil.

Pada penelitian ini akan dilihat pengaruh kondisi dan lama penyimpanan, di mana pupuk tersebut diperlakukan dengan kondisi yang berbeda yaitu disimpan dalam ruangan dengan suhu terkontrol $\left(25^{\circ} \mathrm{C} \pm 3\right.$ ) dan dibandingkan dengan penyimpanan di luar ruangan dengan kondisi terkena panas matahari dan hujan. Dari perlakuan penyimpanan tersebut diharapkan dapat diperoleh suatu kesimpulan penyimpanan pupuk yang baik sehingga diperoleh konsistensi mutu pupuk NPK yang stabil dari produsen sampai ke tangan konsumen.

\section{BAHAN DAN METODE}

Bahan dan peralatan yang digunakan dalam penelitian ini adalah pupuk NPK yang diambil di pasaran sebanyak 2 merk dengan diberi kode sample A dan B serta bahan kimia untuk pengujian. Peralatannya antara lain tabung reaksi, pipet, neraca analitik, penangas air dan lain lain.

Tahap penelitian yang dilakukan yaitu pengambilan contoh dari toko pupuk, kemudian dilakukan pengujian awal untuk melihat kondisi dan parameter yang tertulis di label. Selanjutnya pupuk 
dikondisikan di dalam dan di luar ruangan serta disimpan selama 2 dan 4 minggu.

Pengujian dilakukan sesuai Standar Nasional Indonesia No. 02-2803-2000 dengan parameter Nitrogen Total, Fosfor larut asam sitrat $2 \%$ sebagai $\mathrm{P}_{2} \mathrm{O}_{5}$, Kalium sebagai $\mathrm{K}_{2} \mathrm{O}$ dan Kadar Air.

\section{HASIL DAN PEMBAHASAN}

Sebelum dilakukan penelitian, pupuk yang dibeli di toko diuji kadar Nitrogen, Phospat dan Kalium seperti parameter yang tertulis di kemasan. Perbedaan antara tulisan di kemasan dan hasil uji dapat dilihat pada table di bawah ini :

Tabel 1. Hasil Pengujian Pupuk NPK

\begin{tabular}{|c|c|c|c|c|c|c|}
\hline \multirow{2}{*}{ Merk } & \multicolumn{3}{|c|}{ Kemasan } & \multicolumn{3}{c|}{ Hasil Uji } \\
\cline { 2 - 7 } & $\mathrm{N}$ & $\mathrm{P}$ & $\mathrm{K}$ & $\mathrm{N}$ & $\mathrm{P}$ & $\mathrm{K}$ \\
\hline $\mathrm{A}$ & 20 & 10 & 10 & 18.26 & 13.94 & 9.09 \\
\hline $\mathrm{B}$ & 15 & 15 & 15 & 14.49 & 18.69 & 14 \\
\hline
\end{tabular}

Catatan : N sebagai Nitrogen Total

$\mathrm{P}$ sebagai $\mathrm{P}_{2} \mathrm{O}_{5}$

Ksebagai $\mathrm{K}_{2} \mathrm{O}$

Dari hasil uji yang dilakukan pada 0 hari (pada saat pembelian) diperoleh perbedaan nilai uji dengan nilai pada kemasan. Kadar Nitrogen dan Kalium mempunyai nilai uji lebih rendah daripada nilai di kemasan, sedangkan untuk parameter Phospat mepunyai nilai uji lebih tinggi daripada nilai di kemasan. Perbedaan hasil tersebut dipengaruhi oleh tidak konsistensinya produk ataupun kondisi penyimpanan.

Selanjutnya pupuk NPK dikemas ulang dan dikondisikan di dalam dan di luar ruangan. Hasil dari perlakuan tersebut didapat hasil uji sebagai berikut:

\section{Kadar Nitrogen Sebagai Nitrogen Total}

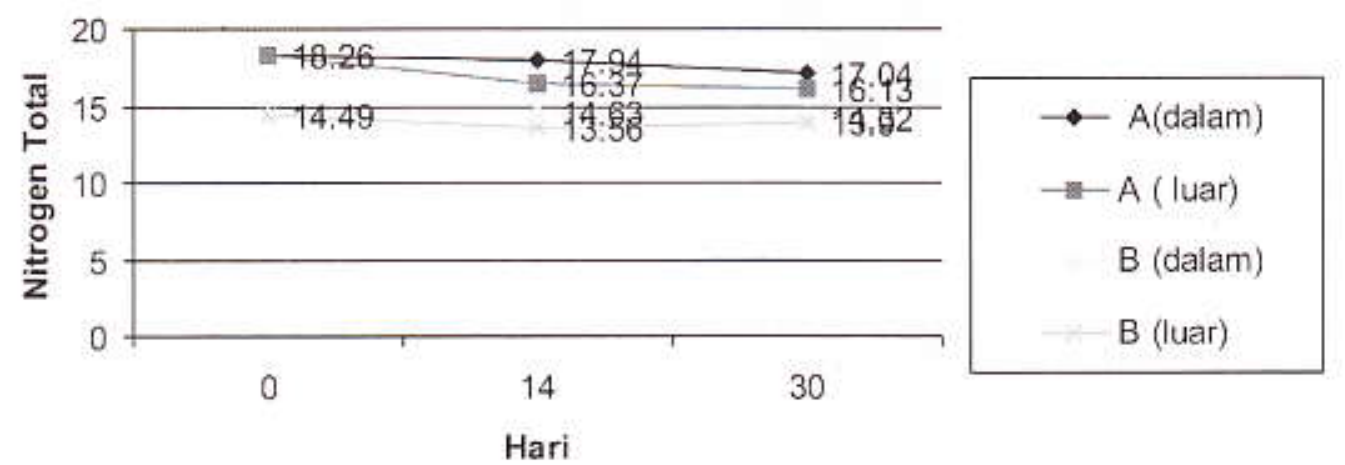

Gambar 1. Grafik Nitrogen sebelum dan sesudah perlakuan

Dari grafik terlihat bahwa kadar Nitrogen total mengalami penurunan. Ini terlihat dari nilai yang tertulis di kemasan untuk pupuk merk A sebesar $20 \%$, setelah diuji didapat hasil $18,26 \%$, sedang untuk pupuk merk B di kemasan tertulis 15\%, dari hasil pengujian diperoleh 14,49\%. Dari hasil Penelitian, dimana pupuk yang dibeli kemudian dikemas ulang dan diperlakukan di dalam dan luar ruangan, terlihat bahwa kadar Nitrogen Total mengalami perubahan. Pada penyimpanan dalam kurun waktu 30 hari saja mengalami penurunan sebesar $6,6 \%$ untuk pupuk NPK A dan 1,17\% untuk $B$. Pupuk $A$ mengalami penurunan yang lebih besar dibanding dengan $B$, karena Pupuk $A$ kadar Nitogennya berasal dari butiran pupuk Urea yang berbentuk prill. Urea Prill merupakan pupuk Nitrogen yang populer digunakan di bidang pertanian karena paling banyak beredar di pasaran dan merupakan pupuk padat yang kandungan Nitrogennya paling tinggi serta reaksinya paling cepat terlihat pada tanaman. Urea Prill bila ditinjau dari segi efisiensinya masih jauh dari yang diharapkan. Karena pupuk bentuk ini mudah terjadi kehilangan unsur Nitrogen. Pupuk ini mudah 
mengalami penguapan, pencucian/leaching karena merupakan pupuk yang bersifat higroskopis (mudah menarik uap air). Sedang untuk pupuk B penurunannya lebih kecil. Hal ini disebabkan karena bentuk campuran pupuk tersebut terdiri dari Urea berbentuk granul, yang mempunyai ukuran butir yang lebih besar. Kelebihan dari pupuk berbentuk granul antara lain tingkat kehilangan unsur hara Nitrogen karena penguapan maupun pencucian lebih kecil di banding pupuk berbentuk prill. Karena mempunyai ukuran yang lebih besar dan tidak mudah lengket sehingga proses penyimpanannya bisa lebih lama.

Untuk penyimpanan di luar ruangan terlihat perbedaan dibanding penyimpanan di dalam ruangan. Untuk pupuk A terjadi penurunan hingga $11,66 \%$, sedang untuk B sebesar $4,07 \%$. Ini disebabkan karena unsur Nitrogen yang terdapat dalam pupuk urea mempunyai sifat yang mudah larut dalam air. Pada kelembaban $73 \%$, pupuk ini sudah mampu menarik uap air dari udara sekitar. Pupuk ini akan mudah berubah menjadi Amonia dan Karbondioksida, di mana kedua zat ini berupa gas yang mudah menguap. Sifat lainnya adalah mudah terbakar oleh sinar matahari.

\section{Kadar Phospat Sebagai P2O5}

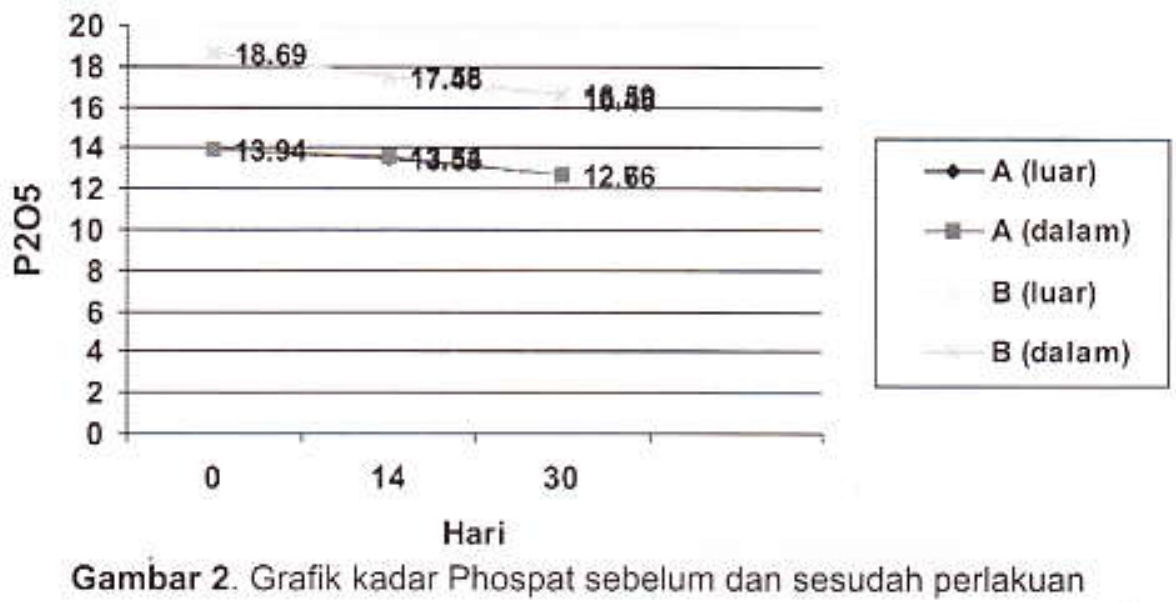

Dari grafik terlihat bahwa kadar Phospat sebagai $\mathrm{P}_{2} \mathrm{O}_{5}$ mengalami penurunan. Nilai yang tertulis di kemasan untuk pupuk merk A sebesar $10 \%$, setelah diuji didapat hasil $13,94 \%$, sedang untuk pupuk merk B di kemasan tertulis $15 \%$, dari hasil pengujian diperoleh $18,69 \%$. Hasil uji yang didapat lebih tinggi dibanding dengan kemasan. Tetapi dari hasil penelitian, dimana pupuk yang dibeli kemudian dikemas ulang dan diperlakukan di dalam dan luar ruangan, terlihat bahwa kadar $\mathrm{P}_{2} \mathrm{O}_{5}$ mengalami perubahan. Pada penyimpanan di dalam ruangan dalam kurun waktu 30 hari mengalami penurunan sebesar $8,9 \%$ untuk pupuk NPKAdan $11,24 \%$ untuk B.

Untuk penyimpanan di luar ruangan hasil uiji menunjukan untuk pupuk $A$ terjadi penurunan hingga $9,18 \%$, sedang untuk $B$ sebesar $11,93 \%$.

\section{Kadar Kalium Sebagai K2O}

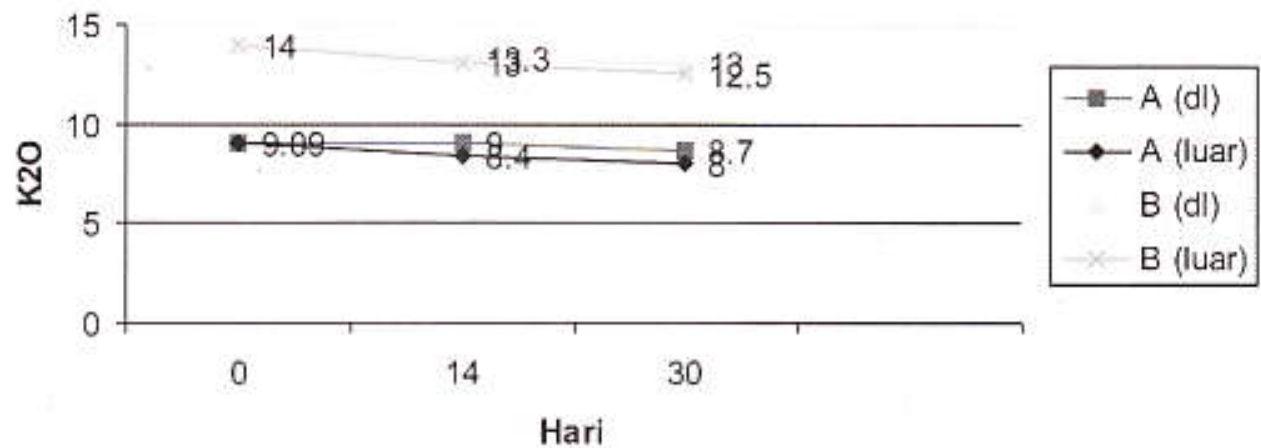


Dari grafik terlihat bahwa kadar Kalium sebagai $\mathrm{K}_{2} \mathrm{O}$ mengalami penurunan. Ini terlihat dari nilai yang tertulis di kemasan untuk pupuk merk A sebesar $10 \%$, setelah diuji didapat hasil $9,09 \%$, sedang untuk pupuk merk B di kemasan tertulis $15 \%$, dari hasil pengujian diperoleh $14 \%$. Dari hasil penelitian, dimana pupuk yang dibeli kemudian dikemas ulang dan diperlakukan di dalam dan luar ruangan, terlihat bahwa kadar $\mathrm{K}_{2} \mathrm{O}$ juga mengalami perubahan. Pada penyimpanan di ruangan dalam kurun waktu 30 hari mengalami penurunan sebesar $4,29 \%$ untuk pupuk NPKA dan $7,14 \%$ untukB.

Untuk penyimpanan di luar ruangan terlihat perbedaan dibanding penyimpanan di dalam ruangan. Untuk pupukA terjadi penurunan hingga $11,99 \%$, sedang untuk $B$ sebesar $10,71 \%$.

Kadar air

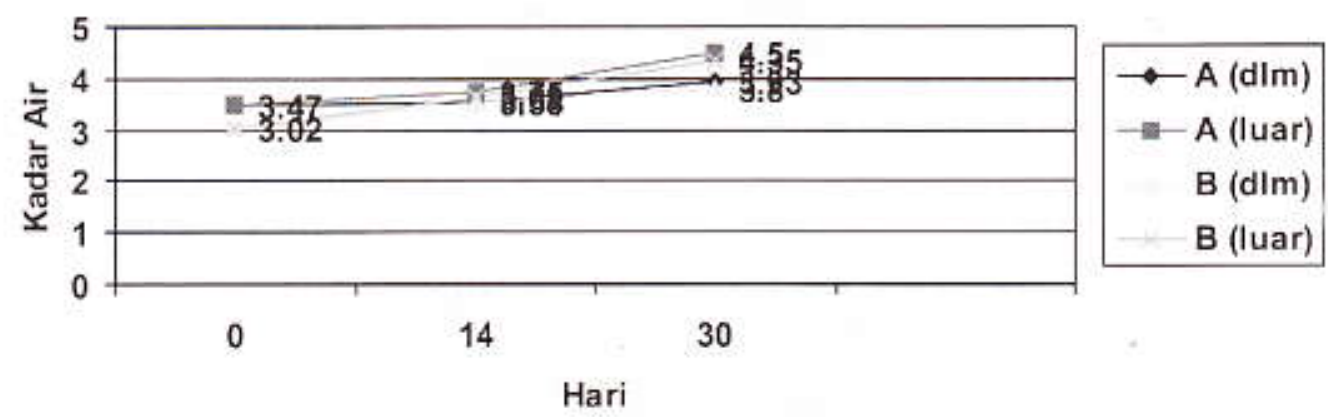

Dari grafik terlihat kenaikan kadar air terutama penyimpanan di luar ruangan. Karena pupuk NPK mempunyai sifat mudah menyerap air dan mudah larut dalam air. Dalam kondisi kehujanan dan terkena sinar matahari, kenaikan kadar air terlihat nyata. Pada penyimpanan 30 hari di luar ruangan, pupukA mengalami kenaikan sebesar $29,7 \%$, sedang untuk B sebesar $44 \%$.

\section{KESIMPULAN}

Dari hasil penelitian yang dilakukan dapat diambil kesimpulan bahwa pupuk NPK adalah pupuk yang mengandung unsur Nitrogen, Phospat dan Kalium, dimana unsur unsur tersebut mempunyai kandungan yang mudah larut dalam air dan tidak tahan terhadap sinar matahari (panas), sehingga mudah terjadi penguapan (volatilisasi), terutama untuk unsur Nitrogen. Dari perlakuan penyimpanan di dalam dan luar ruangan, terlihat bahwa semua unsur pupuk NPK mengalami penurunan di mana penurunan unsur yang paling besar adalah penyimpanan di luar ruangan. Untuk perlakuan lama penyimpanan, penyimpanan dalam waktu 2 minggu berbeda dengan penyimpanan untuk waktu 4 minggu baik di dalam maupun di luar ruangan. Waktu yang lama, menyebabkan hasil uji untuk unsur pupuk NPK mengalami penurunan.Untuk hasil uji kadar air, pupuk yang dikondisikan kepanasan dan kehujanan mengalami peningkatan kadar air yang tinggi dibanding yang disimpan di dalam ruangan. 


\section{DAFTAR PUSTAKA}

BSN, 2000, Standar Nasional Indonesia No. 02-2803-2000, Jakarta

http://www.warungpupuk.com

Indranada K. Henry, 1994, Pengelolaan Kesuburan Tanah, Bumi Aksara, Jakarta

Indriani, HY, 2002, Penebar Swadaya, Jakarta

Lingga, Pinus dan Marsono, 2003, Petunjuk Penggunaan Pupuk, Penebar Swadaya, Jakarta

Murbandono, 1997, Membuat Kompos, Penebar Swadaya, Jakarta

Mulat Tri, 2003, Membuat dan Memanfaatkan Kascing Pupuk Organik Berkualitas, Agromedia

Pustaka, Jakarta 